\title{
University of the Third Age: the impact of continuing education on the quality of life of the elderly
}

\author{
Chadi Emil Adamo' \\ Marina Tomaz Esper' \\ Gabriela Cunha Fialho Cantarelli Bastos' \\ Ivone Félix de Sousa ${ }^{2}$ \\ Rogério José de Almeida ${ }^{3}$
}

\section{Abstract}

Objective: To verify, among elderly participants of the University of the Third Age (UnATI) of PUC Goiás, Goiania, Brazil, whether quality of life was higher or lower among veteran or first-year participants of the UnATI, and to evaluate if there was a statistically significant difference between the quality of life of men and women or first-years and veterans. Method: An observational case-control study with a quantitative approach was performed with 100 elderly individuals from the UnATI. Fifty first-years and fifty veterans were involved. Two questionnaires were applied, one with sociodemographic data and the other using the World Health Organization Quality of Life - Old (WHOQOL-OLD) scale, which evaluates the quality of life of the elderly. Variance analysis (ANOVA) and multivariate variance analysis (MANOVA) were performed, with $p \leq 0.05$ applied to the relevant statistics. Result: The vast majority of the sample were women (90\%), aged between 60 and 86 years old (average of $68.37 \pm 5.28$ years old). The overall quality of life score was $3.68 \pm 0.50$ (first-years) and $3.87 \pm 0.55$ (veterans). There was a statistically significant difference in the areas: sensory functioning (veterans $=4.28 \pm 0.65$ and firstyears $=3.95 \pm 0.80)(p=0.025)$ and past, present and future activity (veterans $=4.0 \pm 0.72$ and first-years $=3.59 \pm 0.79)(p=0.008)$. Multivariate variance analysis identified that the overall quality of life scores of both men (veterans $=3.15$ and first-years $=4.21$ ) and women (veterans $=3.78$ and first-years $=3.86$ ), were highest after they became veteran students $(p=0.007)$. Conclusion: Veterans had a higher quality of life than first-years. The continuing education provided by UnATI has a positive impact on the quality of life of the elderly.

\footnotetext{
Pontifícia Universidade Católica de Goiás, Escola de Ciências Médicas, Farmacêuticas e Biomédicas, Curso de Medicina. Goiânia, Goiás, Brasil.

2 Pontifícia Universidade Católica de Goiás, Escola de Ciências Sociais e da Saúde, Curso de Psicologia. Goiânia, Goiás, Brasil.

3 Pontifícia Universidade Católica de Goiás, Escola de Ciências Médicas, Farmacêuticas e Biomédicas, Curso de Medicina, Programa de Pós-Graduação em Ciências Ambientais e Saúde. Goiânia, Goiás, Brasil.
}

Correspondence

Rogério José de Almeida

E-mail: rogeriopucgo@gmail.com
Keywords: Elderly. Quality of Life. University of the Third Age. 


\section{INTRODUCTION}

The subject of population aging is currently a much-discussed due to its global nature and the epidemiological, political, economic and social changes that it causes. About $8 \%$ of the world's population is made up of people aged 65 or over, and it is expected that this percentage will continue to increase ${ }^{1}$.

This age growth is the reason for the realization of many studies that seek to identify the perception of the elderly about this new stage in their lives and the context in which they are inserted. The aim is to relate the effect of these perceptions on the quality of life of the elderly, emphasizing the importance of active aging in a society increasingly composed of people over 60 years of age $e^{1-4}$.

In old age, quality of life can be influenced by objective factors such as living conditions, social relations, educational level, occupation of free time and economic capacity, and subjective factors such as personal experiences, affective reactions and psychological constructs such as happiness, mental health, feelings of control, social competence, stress and perceived health ${ }^{5}$.

The focus of the current therapeutic and scientific approach of geriatrics and gerontology is based on the concept of active aging. This refers to the "process of the optimization of opportunities of health, participation and safety, with the objective of improving quality of life as people get older"*. This perspective is also anchored in the concepts of autonomy, independence, quality of life and healthy life expectancy ${ }^{6}$.

In this context, there is a new social sensitivity towards old age, which has been reflected in the creation of public policies focused on the needs of the elderly $y^{3,7}$. For example, university programs have been developed for the elderly population. Originally conceived by Pierra Vellas in 1973 in France, these spaces were created to improve the health of the elderly and modify their image among society ${ }^{8}$.

In Brazil, this model was readapted and instituted by Dr. Américo Piquet Carneiro in 1992 in Rio de
Janeiro. Entitled Open Universities of the Third Age (U3A), these spaces aim to offer an alternative way in which the elderly can use their free time in a cultural, social and sporting manner. In addition, they also aim to integrate the elderly with different generations, as well as updating and acquiring new knowledge, enabling integral participation and the elevation of self-esteem, aiming to improve the quality of life of this population groupl ${ }^{7-9}$.

The Pontifícia Universidade Católica de Goiás (Pontifical Catholic University of Goiás) (PUC Goiás), lócus of the present study, offers this service, which is linked to the Social Gerontological Extension Program of the institution. In PUC Goiás, the U3A has been running for 22 years and offers 39 workshops distributed into 52 class groups with the aim of offering continued education.

But, what is the relationship between continuing education through a U3A and the quality of life of the elderly? The present article is motivated by the fact that although there are a large number of studies about the quality of life of the elderly and factors related to it, little is known about the effectiveness of the educational programs for the elderly provided by U3As in improving quality of life. Is there a statistically significant difference between veteran and first-year students of the U3A PUC Goiás in terms of quality of life in aspects of sensory functioning, autonomy, past, present and future activities, social participation, death and dying, intimacy and general quality of life? In addition to the biological aspects of the elderly, and diseases, medications and treatments, there is a need to understand more about this population and the factors inherent to their quality of life.

In this sense, the focus of the analysis of the issue studied is the perspective of elderly people who already participate in U3A PUC Goiás as veteran students and those who are new to the activities of the institution, and their quality of life. The aim of this study was to verify whether quality of life is greater or lesser among the cases (veterans participating in the U3A) or the controls (first-year students) and to evaluate if there is a statistically significant difference between men and women, first-years and veterans in obtaining quality of life. 


\section{METHOD}

An observational case-control study was performed $^{10}$. The research was conducted at U3A PUC Goiás, Goiânia, Brazil. Elderly persons of both genders were studied and separated into two groups: a) students (veterans) who had participated in the activities of the U3A for more than two years; B) students beginning U3A activities in the semester in which the research was carried out, between February and May 2016 (first-years). Fifty students were interviewed in each group, according to the sample plan described below.

The representativeness of the participants of the research was calculated from the formula chosen by the convenience selection method ${ }^{11}$, since the choice of the sample was made intentionally, based on the ease of access and availability of the students of the U3A, who have little available time to take part in studies. Thus, the definition of sample size met the inclusion and exclusion criteria.

The inclusion criteria for the veterans were: attend the university for more than two years, with participation in three workshops with the aim of developing aspects of quality of life (sensory functioning, autonomy, social participation, death and dying, intimacy, past, present and future activities); and be aged 60 years or over.

The inclusion criteria for the first-years were: participation in the U3A of PUC Goiás for the first time; age 60 years or over; and participation for the first time in workshops with the aim of developing aspects of quality of life (sensory functioning, autonomy, social participation, death and dying, intimacy, past, present and future activities).

Exclusion criteria (veterans and first-years): did not respond to more than three items from one of the domains that make up the scales; and participated in other institutions that aim to improve the quality of life of the elderly.

After choosing the participants according to the inclusion criteria, the case group had 57 veteran students who could participate in the study and the control group had 53 first-year students. By entering the numbers of veteran students and first-years in the sample formula, it was found that at least 50 veterans and 47 first-years were required to participate in the survey. Thus, since it was possible to collect data from 50 veteran students and 50 first-years, we chose two case and control groups of 50 participants each, following the criteria for finite populations, with a confidence level of $95 \%(\sigma=1.96), p=0.50$, for $q=0.50$ and $\mathrm{E}^{2}=5 \%(\mathrm{E}=0.05)^{12}$.

Two instruments were used to carry out the research. The first was a questionnaire to evaluate sociodemographic and occupational issues with questions related to participation in the U3A (firstyear or veteran), age, gender, skin color/ethnicity, religion, personal income, marital status, children, housing, education and initiative to participate in the program.

The second instrument used was a questionnaire to evaluate the quality of life of the elderly person, the World Health Organization Quality of Life-Old (WHOQOL-OLD). This questionnaire, developed by the World Health Organization (WHO), was adapted and validated in Brazil by researchers from the Federal University of Rio Grande do Sul ${ }^{13}$. It seeks to develop and test quality of life in elderly persons and can be used in a wide variety of studies, including cross-cultural investigations, health monitoring, epidemiology, service development, and clinical intervention studies ${ }^{13}$. The WHOQOLOLD is a measuring instrument consisting of 24 items, the answers to which follow a Likert scale ranging from 1 (not at all, very dissatisfied, or very unhappy) to 5 (extremely, very satisfied, or very happy) attributed to six facets, which are: Sensory Functioning, Autonomy, Past, Present and Future Activities, Social Participation, Death and Dying and Intimacy. Each of the facets has 4 questions, with responses ranging from 4 to 20. The higher the scores, the better the quality of life is considered to be. There are three ways of presenting the data: total (from 4 to 20 ), mean (1 to 5 ) and percentage (0 to 100).

In this study, we chose to perform the analyzes based on the means, and so the results regarding quality of life can be assessed according to the scale: needs to improve (when the mean is from 1 to 2.9); fair (when the mean is from 3 to 3.9); good (when the mean is from 4 to 4.9) and very good (when the mean is 5$)^{13,14}$. 
The WHOQOL-OLD was evaluated based on the syntax proposed by the WHOQOL-OLD Group ${ }^{13,14}$. The scale values were first inverted for questions 1, 2, 6, 7, 8, 9 and 10; and each question was then grouped into its domain.

The next step was to perform a descriptive analysis of the variables using mean, frequency and standard deviation. Thus, the means of the items were calculated and they were then grouped in each domain, according to the standardization of the WHOQOL-OLD correction proposed by the authors ${ }^{13,14}$. As the psychological attributes are mostly of an interval nature an interval scale was created, so that the constructs related to quality of life could be evaluated through inferential statistics ${ }^{15}$.

The variance analysis (ANOVA) and multivariate analysis of variance (MANOVA) were used to evaluate whether or not there were statistically significant differences $(\mathrm{p} \leq 0.05)$ between the independent and multiple variables.

All the items of the occupational sociodemographic questionnaire were categorized and described by means of frequency and percentage, except for age, which was treated as a scalar variable and, therefore, frequency, percentage, mean, standard deviation and age range were described.

Before the application of the questionnaire all the elderly persons read and signed a Free and Informed Consent Form, which clearly explained the guarantee of confidentiality regarding the identity of the participant. The study was registered on the Plataforma Brasil (the Brazil Platform) of the Department of Health under protocol number CAAE: 52509215.7.0000.0037, approved by the Ethics Research Committee of the Pontifícia Universidade Católica de Goiás under opinion $\mathrm{n}^{\circ}$ 1.420.660.

\section{RESULTS}

The survey included $100 \mathrm{U} 3 \mathrm{~A}$ students from PUC Goiás, of whom $50(50 \%)$ were first-years and $50(50 \%)$ were veterans. The two groups presented a statistically significant difference in relation to personal income $(p=0.016)$ and gender $(p=0.046)$. In relation to personal income, the majority of the group of veterans had an income between one and three minimum wages, while the first-years, in the majority, had an income of one minimum salary. Regarding gender, the group of first-years (84\%) and veterans $(96 \%)$ were composed mostly of women, however in the veteran group the percentage of men was lower (4\%) than in the group of first-years $(16 \%)$ (Table 1).

There was no statistically significant difference $(p \leq 0.05)$ in relation to age, skin color/ethnicity, marital status, schooling, religion and initiative to participate in the U3A, which indicates that both groups are comparable (Table 1).

Regarding skin color/ethnicity, 56\% (veterans) and $58 \%$ (first-years) declared themselves to be white, 36\% (veteran) and 32\% (first-years) mixed race $/$ brown, and $8 \%$ (veterans) and $10 \%$ (first-years) black. In this sample, it was observed that $74 \%$ of the veterans and $72 \%$ of the first-years said they were catholic; $14 \%$ of the veterans and $10 \%$ of the firstyears described themselves as evangelical protestant; and $2 \%$ of the veterans and $8 \%$ of the first-years said they were spiritists. The majority in the veteran group declared themselves to be widowed $(40 \%)$, whereas in the first-year group the majority said they were married (32\%). Regarding schooling, most veterans (44\%) and first-years reported having a high school education $(34 \%)$ (Table 1).

In terms of the initiative to participate in U3A, both the veteran group (46\%) and first-year group $(52 \%)$ said that they decided to participate based on their own initiative. In the next category in both groups, $40 \%$ of veterans and $24 \%$ of firstyears reported being brought by friends and $8 \%$ of veterans and $22 \%$ of first-years described having been brought by their relatives (Table 1).

The general analysis of the quality of life of the elderly group from this U3A, performed using the data collected with the WHOQOL-OLD, revealed a total quality of life of $3.68 \pm 0.50$ (first-year students) and $3.87 \pm 0.55$ (veterans) in comparative analysis (Table 2).

When evaluating the domains of the WHOQOLOLD, it was observed that the mean Sensory Function domain scores of the veteran students $(4.28 \pm 0.65)$ were higher than those of the first-years $(3.95 \pm 0.80)$ 
and that this difference was statistically significant $(p=0.025)$. This difference was also identified in the Past, Present and Future domain, in which the veterans had a mean score of $4.0 \pm 0.72$ and the first-years had a mean score of $3.59 \pm 0.79$, with $p=0.008$ ('Table 2).

Table 1. Socio demographic variable of students at U3A PUC Goiás, by veteran (case) and first-year (control) groups. Goiânia, Goiás, 2016.

\begin{tabular}{|c|c|c|c|}
\hline Variables & First-year & Veteran & $p$-value \\
\hline Age (years) & & & 0.587 \\
\hline 60 to 69 & $30(60 \%)$ & $32(64 \%)$ & \\
\hline 70 to 79 & $17(34 \%)$ & $17(34 \%)$ & \\
\hline 80 to 90 & $3(6 \%)$ & $1(2 \%)$ & \\
\hline Gender & & & 0.046 \\
\hline Male & $8(16 \%)$ & $2(4 \%)$ & \\
\hline Female & $42(84 \%)$ & $48(96 \%)$ & \\
\hline Skin color/ethnicity & & & 0.884 \\
\hline White & $29(58 \%)$ & $28(56 \%)$ & \\
\hline Black & $5(10 \%)$ & $4(8 \%)$ & \\
\hline Brown/mixed-race & $16(32 \%)$ & $18(36 \%)$ & \\
\hline Marital status & & & 0.471 \\
\hline Single & $13(26 \%)$ & $9(18 \%)$ & \\
\hline Married & $16(32 \%)$ & $13(26 \%)$ & \\
\hline Widowed & $13(26 \%)$ & $20(40 \%)$ & \\
\hline Divorced & $8(16 \%)$ & $8(16 \%)$ & \\
\hline Monthly personal income (minimum salary) & & & 0.016 \\
\hline Up to 1 & $21(42 \%)$ & $7(14 \%)$ & \\
\hline From 1 to 3 & $13(26 \%)$ & $23(46 \%)$ & \\
\hline From 4 to 6 & $10(20 \%)$ & $8(16 \%)$ & \\
\hline Over 6 & $5(10 \%)$ & $9(18 \%)$ & \\
\hline None & $1(2 \%)$ & $3(6 \%)$ & \\
\hline Schooling & & & 0.466 \\
\hline Illiterate & $6(12 \%)$ & $2(4 \%)$ & \\
\hline Can read and write & $4(8 \%)$ & $4(8 \%)$ & \\
\hline Elementary school & $7(14 \%)$ & $4(8 \%)$ & \\
\hline High school & $17(34 \%)$ & $22(44 \%)$ & \\
\hline Higher education & $16(32 \%)$ & $18(36 \%)$ & \\
\hline Religion & & & 0.398 \\
\hline No & $2(4 \%)$ & $2(4 \%)$ & \\
\hline Catholic & $36(72 \%)$ & $37(74 \%)$ & \\
\hline Evangelical protestant & $5(10 \%)$ & $7(14 \%)$ & \\
\hline Spiritist & $4(8 \%)$ & $1(2 \%)$ & \\
\hline Umbanda & $0(0 \%)$ & $2(4 \%)$ & \\
\hline Christian & $3(6 \%)$ & $1(2 \%)$ & \\
\hline Initiative to participate in $\mathrm{U} 3 \mathrm{~A}$ & & & 0.148 \\
\hline Own initiative & $26(52 \%)$ & $23(46 \%)$ & \\
\hline Brought by friends & $12(24 \%)$ & $20(40 \%)$ & \\
\hline Brought by family members & $11(22 \%)$ & $4(8 \%)$ & \\
\hline Heard about & $1(2 \%)$ & $2(4 \%)$ & \\
\hline Informed by third parties & $0(0 \%)$ & $1(2 \%)$ & \\
\hline
\end{tabular}

Frequency and percentage $(\mathrm{N} \pm \%)$; Chi-squared statistical significance test $(p \leq 0,05)$ 
Table 2. Comparative analysis of quality of life in first-year and veteran groups by WHOQOL-OLD in a sample of 100 students from U3A PUC Goiás. Goiânia, Goiás, 2016.

\begin{tabular}{lllll}
\hline WHOQOL-OLD Domains & First-year & Veteran & F & -value \\
\hline Sensory functioning & $3.95( \pm 0.797)$ & $4.28( \pm 0.648)$ & 5.16 & 0.025 \\
Autonomy & $3.68( \pm 0.734)$ & $3.79( \pm 0.983)$ & 0.402 & 0.528 \\
Present, past and future activity & $3.59( \pm 0.79)$ & $4.0( \pm 0.72)$ & 7.353 & 0.008 \\
Social participation & $3.72( \pm 0.815)$ & $3.95( \pm 0.722)$ & 2.134 & 0.147 \\
Death and dying & $3.81( \pm 0.976)$ & $3.87( \pm 0.948)$ & 0.114 & 0.736 \\
Intimacy & $3.36( \pm 1.149)$ & $3.35( \pm 1.057)$ & 0.005 & 0.946 \\
Overall Quality of Life & $3.68( \pm 0.5)$ & $3.87( \pm 0.551)$ & 3.174 & 0.078 \\
\hline
\end{tabular}

Mean and standard deviation M ( \pm sd); ANOVA (F) statistical tests; Significance $(\mathrm{p} \leq 0.05)$

Multivariate analysis of variance (MANOVA) revealed that the mean total quality of life scores of veteran U3A students were higher for both the male (first-years $=3.15$ and veterans $=4.21$ ) and the female gender (first-years $=3.78$ and veterans $=3.86$ ), and that the difference was statistically significant $(p=0.007)$ (Table 3).

It was observed that the veteran group $(p=0.006)$ presented better results for both men
$(\mathrm{M}=4.63 \pm 0.530)$ and women $(\mathrm{M}=4.27 \pm 0.653)$ in the Sensory Function domain. It was also found that the veteran group $(p=0.031)$ had better results for both men $(\mathrm{M}=4.00 \pm 0.00)$ and women $(\mathrm{M}=3.99 \pm 0.736)$, in relation to Past, Present and Future Activities. It can be seen that that veterans also scored higher in total quality of life than first-years $(p=0.007)$, both for men $(\mathrm{M}=4.21 \pm 0.059)$ and women $(\mathrm{M}=3.83 \pm 0.558)$ (Table 3).

Table 3. Comparative analysis of quality of life with WHOQOL-OLD between groups of 50 first-year students and 50 veteran students of U3A PUC Goiás distributed by gender (first-years $-\mathrm{N}^{\text {female }}=42, \mathrm{~N}^{\text {male }}$ 8; veterans $\mathrm{N}^{\text {female }}=48 ; \mathrm{N}^{\text {male }}$ 2). Goiânia, Goiás, 2016.

\begin{tabular}{llll}
\hline WHOQOL-OLD (Domains) & M \pm sd & F & $p$-value \\
\hline Sensory Functioning & & 7.744 & 0.006 \\
First-year & & & \\
Male & $3.22 \pm 1.114$ & \\
Female & $4.09 \pm 0.651$ & & \\
Veteran & & & \\
Male & $4.63 \pm 0.53$ & 2.146 \\
Female & $4.27 \pm 0.653$ & \\
Autonomy & & & \\
First-year & & \\
Male & $3.22 \pm 0.281$ & \\
Female & $3.76 \pm 0.763$ & \\
Veteran & & \\
Male & $4.25 \pm 0.354$ & \\
Female & $3.77 \pm 0.998$ & \\
\end{tabular}


continued from Table 3

\begin{tabular}{|c|c|c|c|}
\hline WHOQOL-OLD (Domains) & $\mathrm{M} \pm \mathrm{sd}$ & $\mathrm{F}$ & $p$-value \\
\hline Past, Present and Future Activities & & 4.794 & 0.031 \\
\hline \multicolumn{4}{|l|}{ First-year } \\
\hline Male & $2.97 \pm 0.795$ & & \\
\hline Female & $3.7 \pm 0.741$ & & \\
\hline \multicolumn{4}{|l|}{ Veteran } \\
\hline Male & $4 \pm 0$ & & \\
\hline Female & $3.99 \pm 0.736$ & & \\
\hline Social Participation & & 2.833 & 0.096 \\
\hline \multicolumn{4}{|l|}{ First-year } \\
\hline Male & $2.94 \pm 0.753$ & & \\
\hline Female & $3.87 \pm 0.745$ & & \\
\hline \multicolumn{4}{|l|}{ Veteran } \\
\hline Male & $3.88 \pm 0.177$ & & \\
\hline Female & $3.95 \pm 0.737$ & & \\
\hline Death and Dying & & 1.419 & 0.236 \\
\hline \multicolumn{4}{|l|}{ First-year } \\
\hline Male & $3.41 \pm 1.093$ & & \\
\hline Female & $3.88 \pm 0.947$ & & \\
\hline \multicolumn{4}{|l|}{ Veteran } \\
\hline Male & $4.38 \pm 0.53$ & & \\
\hline Female & $3.85 \pm 0.959$ & & \\
\hline Intimacy & & 0.948 & 0.333 \\
\hline \multicolumn{4}{|l|}{ First-year } \\
\hline Male & $3.16 \pm 1.457$ & & \\
\hline Female & $3.4 \pm 1.097$ & & \\
\hline \multicolumn{4}{|l|}{ Veteran } \\
\hline Male & $4.13 \pm 0.177$ & & \\
\hline Female & $3.31 \pm 1.066$ & & \\
\hline Total Quality of Life & & 7.555 & 0.007 \\
\hline \multicolumn{4}{|l|}{ First-year } \\
\hline Male & $3.15 \pm 0.345$ & & \\
\hline Female & $3.78 \pm 0.462$ & & \\
\hline \multicolumn{4}{|l|}{ Veteran } \\
\hline Male & $4.21 \pm 0.059$ & & \\
\hline Female & $3.86 \pm 0.558$ & & \\
\hline
\end{tabular}

* Statistical tests: MANOVA (F), Significance ( $p$ ), Frequency (n) 


\section{DISCUSSION}

The results of the statistical analysis firstly revealed that the initiative to participate in the U3A came from the elderly person themselves in the majority of cases ( $49 \%$ of the participants). A study carried out at an U3A in the city of Rio de Janeiro showed that the initial information about the existence of this university program came from family members, friends and acquaintances who recommended that the elderly person enroll in the course. It was also found that a large portion of the elderly displayed resistance to participating in the program, which reveals their fears and uncertainties regarding a new and unknown objective ${ }^{7}$. Another study pointed out that the initiative to participate in the U3A was based on intrinsic reasons or dependent on the wishes of the elderly. Thus, the adherence of the elderly to these university programs is usually voluntary, considering their interests and needs ${ }^{16}$.

Other sociodemographic data worthy of attention is that most of the participants in the present study were widowed, single or divorced. It is observed that the phases of life are being reconstructed in the face of constant changes, among them technological advances, access to information, demand for a continuous education and family changes, with the increase of divorces, remarriages and homosexual relationships ${ }^{17}$. This perspective corroborates the idea that the U3A can act as a tool to minimize the effects of this process, since it aims to promote social contact and the development of new capacities that can help with the understanding and active coping with the repercussions that occur in this phase of life ${ }^{7,18}$.

In this context, attention is drawn to the fact that there was a predominantly female participation in the present study. This is similar to the findings of other studies, in which women comprised about $80 \%$ of those enrolled in the U3A. According to these studies, this predominance in the number of women is related to the fact that their life expectancy is five to eight times greater than that of men. The chance that they become widows and feel lonely is therefore greater. In this scenario, this feeling of loneliness represents a stressful emotional experience in their daily lives and mobilizes these women to seek new social contacts ${ }^{1,3,7,8}$.
The data regarding the feminization of old age identified in the present study corroborates with the perspective that the population is getting older and more feminine, with a larger contingent of women in urban areas, and who live alone. These are women who have studied more and entered the labor market ${ }^{19}$. Moreover, another study, which also identified a greater participation of the female sex in the U3A, found that the concepts considered important in the search for this form of education by the female public were the search for identity and the valorization of memory ${ }^{16}$.

Also in relation to the greater female participation in the U3A, it was found that in spite of the greater life expectancy of women, their health is more compromised than that of men, as they are victims of chronic diseases such as osteoporosis, diabetes, hypertension and arthritis. Studies have shown that over time and with continuous participation in these universities, these health problems begin to diminish and even disappear. These results indicate that seeking the U3A is a form of adjuvant treatment of the morbidities that affect women more $\mathrm{e}^{1,3,7,20}$.

In relation to the comparative data between the first-year and the veteran elderly persons, the WHOQOL-OLD identified a significant improvement in sensory functioning and past, present and future activities. This fact showed that the veteran students of the U3A researched presented a perception of a significant improvement in these aspects when compared to those who were starting their participation in the activities.

The sensory functioning domain evaluates the sensory part of quality of life and the impact of the loss of sensory abilities on the same. Thus, it can be seen that participation in the U3A improved the perception that elderly persons have about their sensorial abilities, which contributes directly to the improvement of their quality of life ${ }^{3}$.

The quality of life of the elderly population especially involves the maintenance of functional capacity and autonomy. As sensory functioning is represented by the maintenance of the senses (hearing, smell, taste and touch), the loss of these capacities can compromise the participation of the elderly in activities and their ability to interact with 
other people, making them dependent on care, with the consequent impairment of their quality of life. However, as U3A provides greater social interaction for the elderly and stimulates biopsychosocial development, it can also stimulate the maintenance of the sensorial functioning of this population, making them feel that an improvement of their senses is occurring that is proportional to the duration of their participation in these programs $\mathrm{s}^{20,21}$.

Moreover, the more active the elderly, the better their state of health, their satisfaction with life and, consequently, the better their quality of $l_{i f e}{ }^{2}$. In addition, active aging makes elderly persons increasingly long-lived, maintaining the expectation of a safe life, with possibilities for social participation accompanied by improvements in health and care conditions, resulting in the preservation of their quality of life ${ }^{22}$.

Another area that showed a significant difference in the present research was past, present and future activities. This assesses the degree of satisfaction of the elderly in relation to the previous and current activities they perform or have performed. In addition, it estimates the expectations of participants that they will continue to register achievements in their lives and is an important condition for increasing quality of life in the elderly ${ }^{20,23}$.

These future expectations and projects are considered to be a way of giving meaning to the existence of individuals as beings who maintain their active mental faculties and are capable of projecting and realizing their desires. Thus, the significant improvement observed in veterans in this domain reflects a greater perception of well-being in projects and experiences already achieved and, consequently, leads to an increase in quality of life $\mathrm{e}^{20,23,24}$.

In addition to the two domains cited, the present study identified a significant improvement in the overall quality of life of veterans of this U3A compared to those who were beginning the activities, which corroborates with other studies, demonstrating that the social participation made possible by these schools, together with the knowledge acquired in them, has a positive impact on the quality of life of the elderly ${ }^{7-9}$.
All these factors, by providing social participation and the development of personal skills, guarantee an active aging and contribute to the increased quality of life of the elderly, besides serving as a tool for the development of health policies aimed at improving the conditions of aging in Brazil ${ }^{20,25}$.

Therefore, it is important to emphasize that enabling active aging also means ensuring, in addition to health, the safety, social participation and autonomy of the elderly. In the third age, whose main characteristics in relation to social behavior are the reduction of sensory capacities and a reduced promptness in response, other abilities can be especially important, such as those that allow social contact to be established and maintained. Several studies have already shown that the positive self-perception of the health of the elderly and the increase in their quality of life are directly related to their participation in the community, such as in the case of those who practice ballroom dancing, physical activity and/or who attend U3As $3,7,8,20$.

\section{CONCLUSION}

Based on the results of the present study, it can be seen that the students in the veterans group of the U3A PUC Goiás presented a better general quality of life than first-year students. Based on these findings, it can be inferred that the U3A causes significant changes in aspects related to sensory functioning and past, present and future activities, as well as quality of life in general, for both men and women.

Therefore, it is inferred from these results that participation in the classes offered by this program tends to improve the perception of the elderly in relation to sensory functioning and diminish the impact of the loss of sensorial abilities on quality of life. In addition, the veteran students had a better perception of past, present and future activities, which reflected a greater satisfaction with their achievements in life and with their desired objectives.

All these parameters can improve the perception of the elderly regarding their quality of life, reflecting a positive perception of themselves and of their position in life in a cultural context, within the set 
of values in which they are inserted, and in relation to their goals, expectations, standards and concerns.

As a $\mathrm{U} 3 \mathrm{~A}$ is a space that aims to promote the education, socialization, health and well-being of the elderly, it is expected that the longer that individuals participate in this type of program, the more sociable and healthy they will feel. These facts contribute to the promotion of active aging, resulting in a better quality of life.

\section{REFERENCES}

1. Modeneze DM, Maciel ES, Vilela Júnior GB, Sonati JG, Vilarta R. Perfil epidemiológico e socioeconômico de idosos ativos: qualidade de vida associada com renda, escolaridade e morbidades. Estud Interdiscip Envelhec. 2013;18(2):387-99.

2. Guimarães ACA, Scotti AV, Soares A, Fernandes S, Machado Z. Percepção da qualidade de vida e da finitude de adultos de meia idade e idoso praticantes e não praticantes de atividade física. Rev Bras Geriatr Gerontol. 2012;15(4):661-70.

3. Santos GS, Cunha ICKO. Avaliação da qualidade de vida de mulheres idosas na comunidade. Rev Enferm Cent.- Oeste Min. 2014;4(2):1135-45.

4. Campos ACV, Ferreira EF, Vargas AMD.

Determinantes do envelhecimento ativo segundo a qualidade de vida e gênero. Ciênc Saúde Coletiva. 2015;20(7):2221-37.

5. Monteiro A, Monteiro E. Envelhecer na atualidade: perspectivas dos idosos [trabalho de conclusão de curso]. Mindelo: Universidade do Mindelo, Escola Superior de Saúde; 2013.

6. World Health Organization. Envelhecimento ativo: uma política de saúde. Brasília, DF: OPAS; 2005.

7. Oliveira DA, Simoneau AS. Os programas universitários para pessoas idosas (UnATIs): um estudo de representação social. Estud Pesqui Psicol. 2012;12(2):446-61.

8. Simoneau A, Oliveira DC. Programa universitário para pessoas idosas: a estrutura da representação social. Arq Bras Psicol. 2011;63(1):11-21.

9. Moliterno ACM, Faller JW, Borghi AC, Marcon SS, Carreira L. Viver em família e qualidade de vida de idosos da Universidade Aberta da Terceira Idade. Rev Enferm UERJ. 2012;20(2):179-84.

10. Medronho RA. Epidemiologia. 2. ed. São Paulo: Atheneu; 2008.
In conclusion, it can be stated that the U3A PUC Goiás works as an important tool to improve the quality of life of the elderly. Thus, identifying that an active aging corresponds to biopsychosocial balance and the integrality of the insertion of the elderly in their environment, we can see both the importance that this program has for society, and the need to carry out more studies like this, as population aging is a global reality and there is a growing need for public policies and programs that promote dignified aging.

11. Richardson RJ, Peres JAS, Wanderley JCV, Correia LM, Peres MHM. Pesquisa social: métodos e técnicas. São Paulo: Atlas; 1999.

12. Fonseca JS, Martins GA. Curso de estatística. 6. ed. São Paulo: Atlas; 1996.

13. Power M, Quinn K, Schmidt S; Whoqol-Old Group. Development of the WHOQOL-OLD module. 2005;14(10):2197-214.

14. Fleck MPA, Chachamovich E, Trentini CM. Projeto WHOQOL-OLD: método e resultados de grupos focais no Brasil. Rev Saúde Pública. 2003;37(6):793-9.

15. Hauck Filho N, Zanom C. Questões básicas sobre mensuração. In: Hutz CS, Bandeira RB, Trentini CM. Psicometria. Porto Alegre: Artmed; 2015. p. 24-43.

16. Camarano AA. Living longer: are we getting older or younger for longer? Vibrant Virtual Braz. 2016;13(1):155-75.

17. Almeida SAP, Oliveira RCS. Envelhecimento digno: inserção da mulher na Universidade Aberta para Terceira Idade. Rev Kairós. 2013;16(5):309-23.

18. Queiroz ZPV, Papaléo Netto M. Envelhecimento bem-sucedido: aspectos biológicos, psicológicos e socioculturais. Importância da sociabilidade e da educação. In: Papaléo Netto M, editor. Tratado de gerontologia. São Paulo: Atheneu; 2007. p. 807-17.

19. Camarano AA. Envelhecimento da população brasileira: continuação de uma tendência. Coletiva. 2011;1(5):1-5.

20. Morsch P, Pereira GN, Navarro JHN, Trevisan MD, Lopes DGC, Bós AJG. Características clínicas e sociais determinantes para o idoso sair de casa. Cad Saúde Pública. 2015;31(5):1025-34.

21. Vitorino LM, Paskulin LMG, Vianna LAC. Qualidade de vida de idosos em instituição de longa permanência. Rev Latinoam Enferm. 2012;20(6):1186-95. 
22. Vicente FR, Santos SMA. Avaliação multidimensional dos determinantes do envelhecimento ativo e idosos de um município de Santa Catarina. Texto \& Contexto Enferm. 2013;22(2):370-8.

23. Tavares DMS, Dias FA, Munardi DB. Qualidade de vida de idosos e participação em atividades educativas grupais. Acta Paul Enferm. 2012;25(4):601-6.
24. Maués CR, Paschoal SMP, Jaluul O, França CC, Jacob Filho W. Avaliação da qualidade de vida: comparação entre idosos jovens e muito idosos. Rev Bras Clin Med. 2010;8(5):405-10.

25. Confortin SC, Giehl MWC, Antes DL, Schneider IJC, D’Orsi E. Autopercepção positive de saúde em idosos: estudo populacional no Sul do Brasil. Cad Saúde Pública. 2015;31(5):1049-60.

Received: October 20, 2016

Reviewed: May 13, 2017

Accepted: June 19, 2017 